\author{
Л. М. Мосула \\ ORCID https://orcid.org/0000-0003-3339-0562 \\ ResearcherID P-3349-2016 \\ Scopus Author ID 33767861100
}

Т. В. Кучер

ORCID https://orcid.org/0000-0001-9879-5590

ResearcherID O-4168-2017

Н. В. Горлачук

ORCID https://orcid.org/0000-0003-3575-6652

ResearcherID P-2922-2016

Тернопільський національний медичний університет імені І. Я. Горбачевського МОЗ Украӥни

\title{
ДОСВІД ВИКЛАДАННЯ ВИБІРКОВОЇ ДИСЦИПЛІНИ «ОСНОВИ ХІМІЧНОЇ МЕТРОЛОГІЇ» ПРИ ПІДГОТОВЦ МАЙБУТНІХ ПРОВІЗОРІВ В УМОВАХ ДИСТАНЦІЙНОГО НАВЧАННЯ
}

\author{
L. M. Mosula, T. V. Kucher, N. V. Horlachuk \\ I. Horbachevsky Ternopil National Medical University \\ EXPERIENCE OF TEACHING THE ELECTIVE COURSE “BASES OF \\ CHEMICAL METROLOGY” IN DISTANCE LEARNING AT TRAINING OF \\ FUTURE PHARMACISTS
}

\begin{abstract}
Анотація. У статті представлений перший досвід викладання вибіркової дисципліни «Основи хімічної метрології» в умовах дистанційного навчання для студентів 2 курсу фармацевтичного факультету Тернопільського національного медичного університету імені І. Я. Горбачевського (спеціальність 226 «Фармація, промислова фармація», денної форми навчання). Курс за вибором «Основи хімічної метрології» закладає основи всіх видів вимірювань у хімії, статистичної обробки результатів хімічного аналізу та визначення валідності результатів кількісного визначення хімічних сполук. Зазначена дисципліна $€$ важливою складовою всебічного розвитку майбутнього фахівця фармацевтичної галузі. У важких для освітнього процесу реаліях, спричинених пандемією COVID-19, THMУ імені I. Я. Горбачевського створив належні умови для повноцінного дистанційного навчання студентів. Студенти мали змогу активно взаємодіяти з викладачем, працюючи в програмі Microsoft Teams y peжимі живого спілкування та використовуючи матеріали СДО Moodle, одержувати змістовні, актуальні та ефективні знання. У статті відображено структуру вибіркової дисципліни «Основи хімічної метрології», особливості проведення лекцій, практичних занять та організації самостійної роботи студентів. Узагальнивши набутий досвід викладання в умовах карантину, автори виокремили позитивні та негативні сторони дистанційної форми навчання. Також висвітлено основні проблемні питання при вивченні зазначеної дисципліни та показані шляхи їх вирішення. Визначено теми, що потребують доопрацювання з метою полегшення розуміння їх студентами. Запропоновано, поряд із традиційним вивченням статистичної обробки результатів аналізу хімічного експерименту, в майбутньому застосовувати комп’ютерні програми математико-статистичної обробки даних, такі, як Microsoft Excel i Statistica, що мають великий набір статистичних функцій та засобів візуальної інтерпретації одержаних результатів.
\end{abstract}

Ключові слова: дистанційна освіта; провізор; хімічна метрологія; вибіркова дисципліна.

Abstract. The article represents the first experience of teaching the elective course "Bases of Chemical Metrology" in distance learning for second-year students of the Faculty of Pharmacy I. Horbachevsky Ternopil National Medical University (specialty 226 "Pharmacy, Industrial Pharmacy", full-time study). The elective course "Bases of Chemical Metrology" forms the bases of all types of measurements in chemistry, statistical processing of chemical analysis results and determining the validity of chemical compounds quantitative determination results. This course is an important component of the comprehensive development of the future specialist in the pharmaceutical field. In the difficult realities for the educational process caused by the COVID-19 pandemic, I. Horbachevsky TNMU has created appropriate conditions for full-fledged distance learning. Students have the opportunity for actively interaction with the teacher, while working in the Microsoft Teams program in the form of live communication and using the materials of SDE Moodle, that gain meaningful, relevant and effective knowledge. The article have been represented the structure of the elective course "Bases of Chemical Metrology", specifics of lectures, practical classes and organization of independent work of students. Summarizing the experience of teaching during quarantine, the authors have been selected the advantages and disadvantages of distance learning.

(ㄱ Л. М. Мосула, Т. В. Кучер, Н. В. Горлачук 
The basic questions at studying of the specified discipline have been presented and problems solving have been shown. Topics that need to be upgrade for better students understanding were determined. We proposed to use computer programs for mathematical and statistical data processing in the future, in addition to the traditional study of the statistical analysis of the chemical experiment results e.g. Microsoft Excel and Statistica that has a wide range of statistical functions and tools for visual interpretation of the results.

Key words: distance education; pharmacist; chemical metrology; elective course.

Вступ. Метрологія та вимірювання єневід’ємними елементами в плануванні процесів, що впливають на розвиток суспільства, економіки та науки. Вимірювання входить практично в усі операції сучасного фармацевтичного виробництва. Хімічна метрологія займається забезпеченням єдності вимірювань у кількісному хімічному аналізі, що надзвичайно важливо при виробництві та контролі якості лікарських засобів (ЛЗ). Метою вивчення хімічної метрології є формування системних знань, набуття вмінь здійснювати вибір оптимальних вимірювальних засобів з урахуванням завдань та вимог хімічних досліджень, практичних навичок з підвищення точності вимірювань, опрацювання одержаних результатів методами математичної статистики та коректного їх представлення [2, 7, 10]. Характеристики продукції та їі відповідність стандартам $€$ істотними критеріями у фармації. Так, стандарт ISO вимагає того, щоб організація визначала види діяльності щодо забезпечення моніторингу та вимірювань. Завдання забезпечення коректних вимірювань через повірку вимірювальних інструментів i нагляду за їх використанням є базовим для фармацевтичної галузі. Для цього необхідні персонал відповідного рівня, сучасні стандарти та вимірювальне обладнання [6].

В умовах сьогодення, спричинених пандемією COVID-19, практично всі країни світу змушені були перейти на дистанційну форму навчання. Не стала винятком і Україна та ТНМУ імені I. Я. Горбачевського зокрема. Дистанційна форма навчання дала можливість створення системи безперервного навчання та самонавчання, загального обміну інформацією. Саме така форма навчання найбільш ефективно та гнучко відреагувала на потреби суспільства в умовах пандемії COVID-19 для підготовки професіоналів фармацевтичної галузі. Вона передбачає відведення більшої частини навчальних годин на самостійне опрацювання студентом матеріалу за розробленою викладачем програмою та онлайн-взаємодію учасників навчального процесу за допомогою сучасних інформаційних технологій. Дистанційна форма навчання включає більшість притаманних стаціонарному навчанню елементів, таких, як: живе спілкування, групові дискусії та колективне обговорення пройденого матеріалу $[1,11]$.
Мета статті - проаналізувати ефективність викладання вибіркової навчальної дисципліни «Основи хімічної метрології» для студентів 2 курсу фармацевтичного факультету ТНМУ імені I. Я. Горбачевського (спеціальність 226 «Фармація, промислова фармація», денної форми навчання) в умовах дистанційного навчання, врахувати переваги і недоліки такої форми навчання та зробити висновки щодо покращення освітнього процесу.

Теоретична частина. У теперішніх умовах навчання студенти мають змогу обирати деякі навчальні дисципліни. Обсяг вибіркових навчальних дисциплін, передбачений відповідною освітньою програмою та навчальним планом, становить не менше як 25 \% загальної кількості кредитів ЄKТС, передбачених для даного рівня вищої освіти [9]. Серед чотирьох дисциплін, представлених на вибір студентам 2 курсу фармацевтичного факультету ТНМУ імені І. Я. Горбачевського, дві - викладаються на кафедрі фармацевтичної хімії. Зокрема, основи хімічної метрології та фармацевтичні аспекти тютюнокуріння, алкоголізму, токсикоманії та наркоманії [8]. Цьогоріч вибіркова дисципліна «Основи хімічної метрології» була обрана близько 50 \% студентів курсу, що говорить про усвідомлення важливості даного предмета для майбутньої професійної діяльності, адже без знання основ хімічної метрології неможливий належний контроль якості ЛЗ та фармацевтичне виробництво загалом.

Згідно з навчальним планом підготовки фахівців другого (магістерського) рівня вищої освіти галузі знань 22 «Охорона здоров'я» у закладах вищої освіти МОЗ України за спеціальністю 226 «Фармація, промислова фармація» освітньої кваліфікації «Магістр фармації», вивчення даної дисципліни здійснюється на 2 курсі та її обсяг становить 120 год (лекції - 10 год, практичні заняття - 30 год, самостійна робота студентів - 80 год).

Основи хімічної метрології, як наука, базуються на знаннях з фізики і вищої математики та загальних закономірностях хімічних наук, закладають основи всіх видів вимірювань у хімії, статистичної обробки результатів хімічного аналізу, визначення валідності результатів кількісного визначення хімічних сполук і передбачають формування умінь застосування одержаних знань для вивчення спе- 
ціальних дисциплін та у професійній діяльності. Завданням дисципліни є формування у студентів базових знань стосовно нормативної бази у сфері основ хімічної метрології, контролю та забезпечення якості продукції, обізнаності у питаннях метрологічної діяльності. Основи хімічної метрології, використовуючи результати хімічного експерименту в аналітичній та органічній хімії, закладають студентам підгрунтя для подальшого освоєння профільних дисциплін, таких, як фармацевтична хімія, токсикологічна та судова хімія, стандартизація лікарських засобів тощо.

Для забезпечення студентів необхідними методичними матеріалами розроблено курс лекцій та підготовок до них, методичні вказівки для виконання практичних робіт і підготовки до практичних занять, що є у вільному доступі для всіх учасників навчального процесу нашого університету, адже представлені в системі Moodle на сайті ТНМУ імені I. Я. Горбачевського [5].

Лекційний курс представлений у вигляді п’яти мультимедійних презентацій. Лекції проводилися на платформі Microsoft Teams у вигляді відеоконференції та нарад. Належна підготовка до лекцій передбачала попереднє ознайомлення студентів 3 представленими на сайті університету матеріалами та підготовкою незрозумілих питань, які вони могли поставити лектору безпосередньо під час лекції або написати в чат. Кожен студент отримував відповідь на поставлені питання, а також бралися до уваги зауваження та побажання щодо покращення навчального процесу.

На практичних заняттях студенти вчилися грамотно застосовувати різні засоби вимірювань, забезпечуючи єдність вимірювань, виявляти та мінімізувати похибки вимірювань, проводити статистичне планування хімічного експерименту. Кожне практичне заняття забезпечене методичними рекомендаціями, матеріалами підготовки до нього, тестовими завданнями для контролю знань та ситуаційними задачами. Структура заняття включала обговорення теоретичного матеріалу, перегляд відеоматеріалів виконання практичної роботи, обговорення побаченого та вирішення ситуаційних завдань і розрахункових задач, а також вихідний контроль, представлений переліком теоретичних питань та тестових завдань.

Умовно всі заняття курсу «Основи хімічної метрології» були розділені на дві підгрупи. Перших сім занять охоплювали поняття «метрологія», «фізична величина», «вимірювання» та особливості застосування і калібрування хімічного посуду, а також способи зважувань та вимірювань об'ємів досліджуваних об’єктів у різних агрегатних станах. Наступний блок занять включав вісім тем, пов’язаних із поняттям «похибок» у кількісному хімічному аналізі, їх класифікацією та методами статистичної обробки результатів хімічного експерименту з врахуванням різних критеріїв.

На першому занятті розглядали основні поняття, завдання метрології та основні положення і терміни Закону України «Про метрологію і метрологічну діяльність», структуру Метрологічної служби України та міжнародне співробітництво в галузі метрологічної діяльності [10]. Друге заняття передбачало ознайомлення студентів із поняттям фізичної величини та іï характеристиками, Міжнародною системою одиниць System International (SI), правилами застосування вимог SI в хімії та класифікацією еталонів, а також набуття умінь переведення системних одиниць у позасистемні. На третьому занятті студенти освоювали різноманітні методи вимірювань фізичних величин, знайомилися із необхідними в галузі фармації засобами вимірювань, їх метрологічними характеристиками. Практична робота полягала у визначенні густини рідин згідно з Державною Фармакопеєю України (ДФУ, 2.0, том 1) прямим методом вимірювання та визначенні відносної густини етанолу з використанням алкоголеметричних таблиць [3]. На наступному занятті студенти ознайомлювалися з хімічним посудом загального та спеціального призначення, поняттями «хімічна» і «термічна стійкість скла», типами мірного посуду та їх характеристиками, набували вмінь визначення ціни поділки шкали і меж вимірювання приладів та засобів (циліндра, хімічного стакана, конічної колби тощо) розрахунковим методом. П’яте заняття полягало в опануванні різних видів ваг і терезів, необхідних для роботи в хімічній лабораторії, умов та особливостей їх експлуатації. У ході заняття студенти переглядали відео, на якому представлено зважування речовин у різних агрегатних станах на технічних та аналітичних вагах, і засвоювали особливості взяття їх точної наважки. Важливе значення у виробництві ЛЗ має поняття «насипний об’ єм», тому на шостому занятті студенти освоювали вимірювання об'ємів сипких матеріалів, рідин, газів та твердих тіл; вчилися оцінювати точність результатів вимірювань. Сьоме заняття передбачало знайомство з поняттям «калібрування засобів вимірювання», на якому студенти вивчали порядок проведення повірки 
законодавчо регульованих засобів вимірювальної техніки, способи калібрування засобів вимірювання та визначали класи точності хімічного посуду. Практична частина заняття полягала в калібруванні мірного посуду (піпеток та колб).

Враховуючи те, що достовірні результати вимірювань дають підставу правильно управляти процесами розробки й виробництва продукції, своєчасно вносити корективи у виробничі процеси й операції, регулювати параметри технологічних процесів і процесів контролю якості ЛЗ, на восьмому занятті студенти вивчали похибки в кількісному хімічному аналізі, знайомилися з їх класифікацією, числом значущих цифр результатів вимірювання та правилами заокруглення чисел. Дев’яте заняття продовжувало знайомити студентів з похибками в кількісному аналізі, а саме абсолютною та відносною як формами вираження систематичної похибки, нормальним законом розподілу, а також особливостями застосування інтраполяції та екстраполяції результатів аналізу. Практична частина заняття полягала у розрахунку абсолютної та відносної похибок при вимірюванні густини води за різних температур із подальшим висновком щодо точності вимірювань. Деяких похибок уникнути не вдається, проте можна мінімізувати їх вплив на результати вимірювання, грубі ж промахи обов’язково слід знайти і вилучити з результатів експерименту, інакше - результат буде не достовірним. Враховуючи це, десяте заняття присвячене визначенню випадкових похибок і грубих промахів за різноманітними критеріями. На практичній частині заняття студенти проводили перевірку однорідності вибірки за Q-критерієм та вилучення значень варіант, що випадають. Засвоєнню похибок на заняттях приділялась особлива увага, оскільки без цих вмінь неможлива подальша статистична обробка результатів експерименту, яка включена до ДФУ. На практичній частині одинадцятого заняття студенти знайомилися з методами статистичної обробки результатів аналізу та проводили первинну обробку результатів експерименту, представлених викладачем, визначаючи моду, медіану, вибіркову середню величину, дисперсію. Правильна метрологічна обробка результатів аналізу хімічного експерименту у фармацевтичній галузі повинна керуватися вимогами ДФУ [4], що є запорукою достовірних результатів, а це потребує грунтовних математичних знань для здійснення точних обрахунків. Тому дванадцяте заняття присвячене проведенню статистичного аналізу результатів хі- мічного експерименту згідно з ДФУ. На тринадцятому занятті студенти вчилися порівнювати різні серії результатів аналізу за критерієм Фішера та застосовувати критерій Стьюдента. Вони також знайомилися з метрологічними характеристиками методики аналізу та критеріями Бартлета, Кокрена. Порівнюючи переваги та недоліки цих критеріїв, студенти з'ясували, що вони є взаємодоповнюючими і повинні використовуватися спільно. Чотирнадцята тема була присвячена довірчим інтервалам та оцінці їх величини. На останньому п’ятнадцятому занятті проводився підсумковий модульний контроль за темою «Похибки хімічного аналізу. Статистична обробка даних», котрий містив тестові завдання та теоретичні питання.

Значну частину загальної кількості годин, що дається на опанування вибіркової дисципліни «Основи хімічної метрології», відведено для самостійної роботи студентів. Під час вивчення курсу студентами розроблялися метрологічні кросворди та представлялися доповіді і реферати з відповідних тем навчальної дисципліни.

Висновки та перспективи подальших досліджень. Вивчення вибіркової дисципліни «Основи хімічної метрології» дає можливість готувати фахівців для вирішення низки актуальних завдань у сфері фармацевтичного виробництва та контролю якості ЛЗ, що передбачає забезпечення єдності вимірювань, розроблення, впровадження та експлуатацію інформаційно-вимірювальних приладів, комплексів та систем. В умовах пандемії COVID-19 організована в ТНМУ імені І. Я. Горбачевського дистанційна форма навчання виявилася необхідним та своєчасним підходом для реалізації безперервного освітнього процесу. Серед обмежень такої форми навчання можна зазначити нестабільність роботи Інтернету, недостатню вмотивованість деяких студентів до самоорганізації та активної взаємодії з викладачем. Аналізуючи отриманий досвід дистанційного викладання дисципліни «Основ хімічної метрології», можна зробити висновок про те, які теми потребують доопрацювання з метою полегшення розуміння їх студентами та кращого засвоєння з перспективою застосування набутих вмінь на наступних курсах та в майбутній професійній діяльності. Аналіз успішності студентів із засвоєння знань та навичок різних тем дисципліни дозволяє нам зробити висновок про те, що останні теми курсу далися студентам найважче. Тому в майбутньому плануємо вдосконалити методи подання матеріалу щодо статистичного аналізу ре- 
зультатів хімічного експерименту, адаптувавши їх до наявного рівня сприйняття. Проаналізувавши складності студентів з проведення статистичної обробки результатів хімічного експерименту та враховуючи їх побажання, планується зазначені теми в майбутньому вивчати, застосовуючи комп’ютерні програми математико-статистичної обробки даних. Вибір статистичного пакета аналізу буде залежати

\section{Список літератури}

1. Буленок С. М. Психологічні та педагогічні особливості дистанційного навчання / С. М. Буленок, Л. В. Коваленко // Дистанційне навчання в глобалізованому світі : зб. матеріалів Міжвузівського наук.-метод. семінару / Київ. нац. торг.-екон. ун-т (Київ, 17 лют. 2021 р.). - К., 2021. - С. 11-14.

2. Величко О. М. Метрологія, технічне регулювання та забезпечення якості : у 5 т. Т. 1 : Метрологія : підручник / О. М. Величко, Л. В. Коломієць, Т. Б. Гордієнко. - Одеса : ВМВ, 2014. - 688 с.

3. Державна Фармакопея України : в 3 т. / Державне підприємство «Український науковий фармакопейний центр якості лікарських засобів». - 2-ге вид. - Х. : Державне підприємство «Український науковий фармакопейний центр якості лікарських засобів», 2015. - Т. 1. -1128 с.

4. Державна Фармакопея України / Державне підприємство «Український науковий фармакопейний центр якості лікарських засобів». - 2-ге вид. - Доповнення 2. - Х. : Державне підприємство «Український науковий фармакопейний центр якості лікарських засобів», 2018. - 336 с.

5. Матеріали курсу «Основи хімічної метрології» [Електронний ресурс]. - Режим доступу : https://moodle. tdmu.edu.ua/course/view.php?id=2248.

\section{References}

1. Bulenok, S.M., \& Kovalenko, L.V. (2021). Psykholohichni ta pedahohichni osoblyvosti dystantsiinoho navchannia [Psychological and pedagogical features of distance learning]. Dystantsiine navchannia v hlobalizovanomu sviti: zb. materialiv Mizhvuzivskoho naukovometodychnoho seminaru - Distance learning in a globalized world: collection of materials of the Interuniversity scientific-methodical seminar. Kyiv Natsionalnyi torhovo-ekonomichnyi universytet [in Ukrainian].

2. Velychko, O.M., Kolomiiets, L.V., \& Hordiienko, T.B. (2014). Metrolohiia, tekhnichne rehuliuvannia ta zabezpechennia yakosti: u piaty tomakh. Tom 1: Metrolohiia. Pidruchnyk [Metrology, technical regulation and quality assurance: in five volumes]. Odesa: VMV [in Ukrainian]. від характеру завдань, що розглядаються, та обсягу даних, які обробляються. Серед великої кількості програмного забезпечення перевагу надаватимемо Microsoft Excel та Statistica, які мають не тільки великий набір статистичних функцій: факторний аналіз, регресійний аналіз, кластерний аналіз, а також містять і засоби візуальної інтерпретації отриманих результатів: графіки, діаграми.

6. Настанова СТ-Н МОЗУ 42-4.0:2020. Лікарські засоби. Належна виробнича практика. - К. : МОЗ України, 2020. - 338 с.

7. Нестерчук Д. М. Основи метрології та засоби вимірювань : навч. посіб. / Д. М. Нестерчук, С. О. Квітка, С. В. Галько. - Мелітополь : Видавничо-поліграфічний центр «Люкс», 2017. - 256 с.

8. Освітня програма «Фармація» другого рівня вищої освіти за спеціальністю 226 «Фармація, промислова фармація» галузі знань 22 «Охорона здоров'я». Кваліфікація: Магістр фармації, промислової фармації. Провізор [Електронний ресурс]. - Режим доступу : https:// drive.google.com/file/d/1wEE8xw6GTcVrg8adaIbi0jIJ1A eIPH8n/view.

9. Про вищу освіту : Закон України від 01.07.2014 р. № 1556-VII [Електронний ресурс]. - Режим доступу : https://zakon.rada.gov.ua/laws/show/1556-18\#Text.

10. Про метрологію та метрологічну діяльність : Закон України від 15.01.2015 р. № 124-VIII [Електронний ресурс]. - Режим доступу : https://zakon.rada.gov.ua/laws/ show/1314-18\#Text.

11. Пудова С. С. Особливості повного дистанційного навчання іноземних студентів-медиків при вивченні медичної інформатики / С. С. Пудова // Медична освіта. - 2021. - № 1. - С. 44-49. https://doi.org/10.11603/ me.2414-5998.2021.1.11775.

3. (2015). Derzhavna Farmakopeia Ukrainy [State Pharmacopoeia of Ukraine]. (2nd ed.). (Vols. 1-3). Kharkiv: Derzhavne pidpryiemstvo «Ukrainskyi naukovyi farmakopeinyi tsentr yakosti likarskykh zasobiv» [in Ukrainian].

4. (2018). Derzhavna Farmakopeia Ukrainy. Dopovnennia 2 [State Pharmacopoeia of Ukraine. Supplement 2]. (2nd ed.). Kharkiv: Derzhavne pidpryiemstvo «Ukrainskyi naukovyi farmakopeinyi tsentr yakosti likarskykh zasobiv» [in Ukrainian].

5. (2021). Materialy kursu «Osnovy khimichnoi metrolohii» [Materials of the course "Bases of Chemical Metrology”]. Retrieved from: https://moodle.tdmu.edu.ua/course/ view.php?id=2248 [in Ukrainian]. 
6. Nastanova ST-N MOZU 42-4.0:2020. Likarski zasoby. Nalezhna vyrobnycha praktyka [Guidelines ST-N MOHU 42-4.0: 2020. Medicines. Good manufacturing practice]. Kyiv: MOZ Ukrayiny [in Ukrainian].

7. Nesterchuk, D.M., Kvitka, S.O., \& Halko, S.V. (2017). Osnovy metrolohii ta zasoby vymiriuvan: navchalnyi posibnyk [Fundamentals of metrology and means of measurement: educational manual]. Melitopol: Publishing and Printing Center "Lux" [in Ukrainian].

8. Osvitnia prohrama «Farmatsiia» druhoho rivnia vyshchoi osvity za spetsialnistiu 226 «Farmatsiia, promyslova farmatsiia» haluzi znan 22 Okhorona zdorovia. Kvalifikatsiia: Mahistr farmatsii, promyslovoi farmatsii. Provizor [Educational program "Pharmacy" of the second level of higher education in the specialty 226 "Pharmacy, Industrial Pharmacy" in the branch of knowledge 22 Health care. Qualification: Master of Pharmacy, Industrial Pharmacy. Pharmacist]. Retrieved from: https://drive.
google.com/file/d/1wEE8xw6GTcVrg8adaIbi0jIJ1AeIPH 8n/view [in Ukrainian].

9. Zakon Ukrainy Pro vyshchu osvitu vid 01.07.2014 r. № 1556-VII [Law of Ukraine On Higher Education dated 01.07.2014 No. 1556-VII]. Retrieved from: https://zakon. rada.gov.ua/laws/show/1556-18\#Text [in Ukrainian].

10. Zakon Ukrainy Pro metrolohiiu ta metrolohichnu diialnist vid 15.01.2015 r. № 124-VIII [Law of Ukraine On Metrology and Metrological Activity dated 15.01.2015 No. 124-VIII]. Retrieved from: https://zakon.rada.gov.ua/ laws/show/1314-18\#Text [in Ukrainian].

11. Pudova, S.S. (2021). Osoblyvosti povnoho dystantsiinoho navchannia inozemnykh studentiv-medykiv pry vyvchenni medychnoi informatyky [Features of total distance learning for foreign medical students during a study of medical informatics]. Medychna osvita - Medical Education, 1, 44-49 [in Ukrainian].

Електронна адреса для листування: mosula@tdmu.edu.ua

Отримано 31.05.21

Рекомендовано 02.06.21 